DOI: $10.4274 /$ tpa.45.373

\title{
Perinatal letal hipofosfatazya: Olgu sunumu
}

Perinatal lethal hypophosphatasia: Case report

Şenol Bozdağ, Ömer Erdeve, Şerife Suna Oğuz, Tülin Gökmen, Nurdan Uraş, Uğur Dilmen

Zekai Tahir Burak Kadın Sağlığı Eğitim ve Araştırma Hastanesi, Neonatoloji Kliniği, Ankara, Türkiye

\section{Özet}

Perinatal letal hipofosfatazya alkalen fosfataz enzim aktivitesinin eksikliğine bağlı kemik ve diş mineralizyon bozukluğu ile belirgin nadir kalıtımsal bir hastalıktır. Hastalarda intrauterin kemik mineralizasyonunda belirgin azalma görülür. Doğum sonrası palpasyonla yumuşak ve kemik izlenimi vermeyen kafatası ve geniş açık sütürleri olan olgu değerlendirildiğinde üst ve alt ekstremitelerin proksimal kısımlarının distale göre daha kısa olduğu, tibiyaların kısa ve kavisli olduğu saptandı. Radyografik değerlendirmede kemiklerde zayıf mineralizasyon gözlendi. Ağır klinik gidișe ek olarak, serum alkalen fosfataz düzeyinin (=3 IU/L, N:185-350 IU/L) çok düşük saptanması hastada perinatal letal tip hipofosfatazya tanısını destekledi. Burada prenatal tanısı olmadan perinatal letal tip hipofosfatazya tanısı alan bir yenidoğan olgusu sunularak, iskelet deformiteli yenidoğanda nadir görülen bu tablonun tartışılması amaçlanmıştır. (Türk Ped Arş 2010; 45: 373-6)

Anahtar sözcükler: Alkalen fosfataz, hipofosfatazya, perinatal letal hipofosfatazya, yenidoğan

\section{Summary}

Perinatal lethal hypophosphatasia is a rare inherited disorder characterized by due to defective bone and teeth mineralization deficiency of alkaline phosphatase activity. Intrauterine bone mineralization is markedly reduced in affected fetuses. The patient, who presented with soft skull with no impression of bone showed widened sutures, short and bowed tibia in addition to shorter proximal length when compared to distal parts in all extremities. Radiographic evaluation revealed poor bone mineralization. The severe clinical progress in addition to low alkaline phosphatase level (3 IU/L, N:185-350 IU/L) supported the diagnosis of perinatal lethal hypophosphatasia in this patient. We herein present a perinatal lethal hypophosphatasia newborn without prenatal diagnosis and aim to discuss this rare disorder in a newborn with skelatal deformity. (Turk Arch Ped 2010; 45: 373-6)

Key words: Alkaline phosphatase, hypophosphatasia, newborn, perinatal lethal hypophosphatasia

\section{Giriş}

Hipofosfatazya serum ve kemik alkalen fosfataz enzim aktivitesinin eksikliğine bağlı kemik ve diş mineralizyon bozukluğu ile belirgin olan nadir kalıtımsal bir hastalıktır. İlk kez Rathbun (1) tarafından 1948'de tanımlanmıştır. Hastalığın ciddi tiplerinin sıklığı 1/100 000'dir. Bulgular klinik olarak, kemiklerde mineralizasyon göstermeyen ölü doğumdan, kemik bulgusu olmaksızın erken diş kaybıyla giden şekle kadar oldukça geniş bir değişkenlik gösterir. Tanı sırasındaki yaşa bağlı olarak perinatal letal, perinatal selim, süt çocukluğu, çocukluk, yetişkin ve odonto-hipofosfatazya olmak üzere altı klinik tip tanımlanmıştır. Peri- natal letal tipte hastalar intrauterin kemik mineralizasyonunda belirgin azalma gösterirler ve hastalar erken neonatal dönemde kaybedilirler (2).

Burada izlemsiz bir gebede prenatal tanısı olmadan, perinatal letal tip hipofosfatazya tanısı alan bir yenidoğan olgusu sunularak, iskelet deformiteli yenidoğanda nadir görülen bu tablonun tartışılması amaçlanmıştır.

\section{Olgu Sunumu}

Sağlıklı ve eşiyle teyze çocuğu olan 36 yaşındaki annenin üçüncü gebeliğinden üçüncü canlı doğum olarak 38 haftalık, 2380 gr ağırlığında normal kendiliğinden

Yazışma Adresi/Address for Correspondence: Dr. Şenol Bozdağ, Kızıırmak Mah. 48. Cadde 449. Sok No:37/19 Çankaya/Ankara, Türkiye E-posta: senolbozdag@hotmail.com Geliş Tarihi/Received: 25.05.2009 Kabul Tarihi/Accepted: 23.09.2009 Türk Pediatri Arşivi Dergisi, Galenos Yayınevi tarafindan basılmıştır. / Turkish Archives of Pediatrics, published by Galenos Publishing 
vajinal yol ile doğan kız bebek, solunum sıkıntısı ve dismorfik görünümü nedeniyle yenidoğan yoğun bakım birimine yatırıldı. Birinci ve beşinci dakika APGAR skoru sırasılyla 3 ve 5 idi.

Ailenin sağlıklı iki çocuğu vardı. Düşük veya ölü doğum öyküsü bulunmamaktaydı. Bu gebeliğinin izlemsiz olduğu ancak doğumdan hemen önce yapılan ultrasonografide polihidramniyos bulgusu belirlendiği öğrenildi. Ailede benzer öykü veren bir bebek yoktu.

Fizik muayenede, palpasyonla yumușak kıvamda ve kemik izlenimi vermeyen kafatası ve oldukça geniş açık sütürler saptandı. Burun kökü hafif basık ve burun "antevert" pozisyonda idi. Gözler çekik ve yüksek damağı mevcuttu. Göğüs ön arka çapı artmış, meme areolaları ayrık ve göğüs cildinde peteşiyal döküntüler vardı. Üst ve alt ekstremitelerin proksimal kısımları distale göre daha kısaydı. Her iki el ayasında simiyan çizgi belirgindi. Her iki

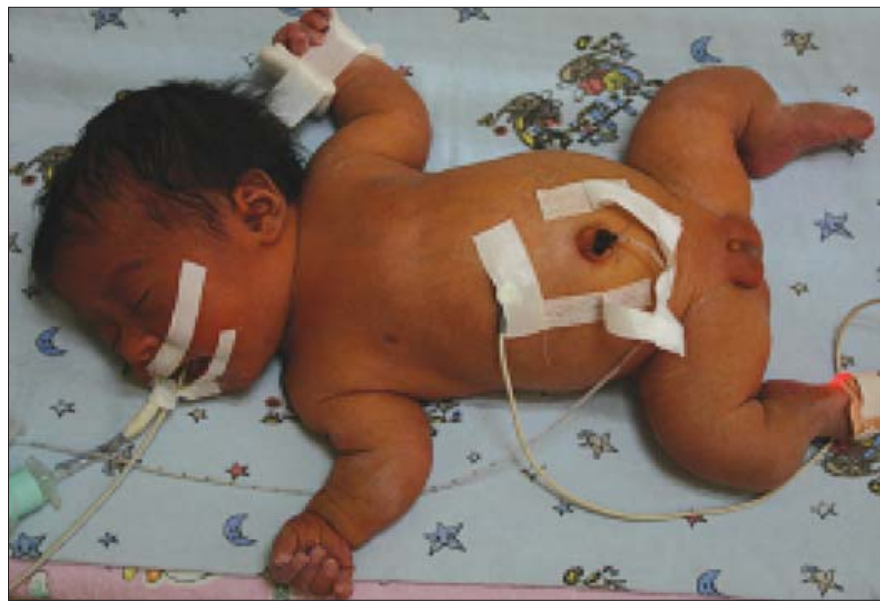

Resim 1. Hastanın genel görünüşü

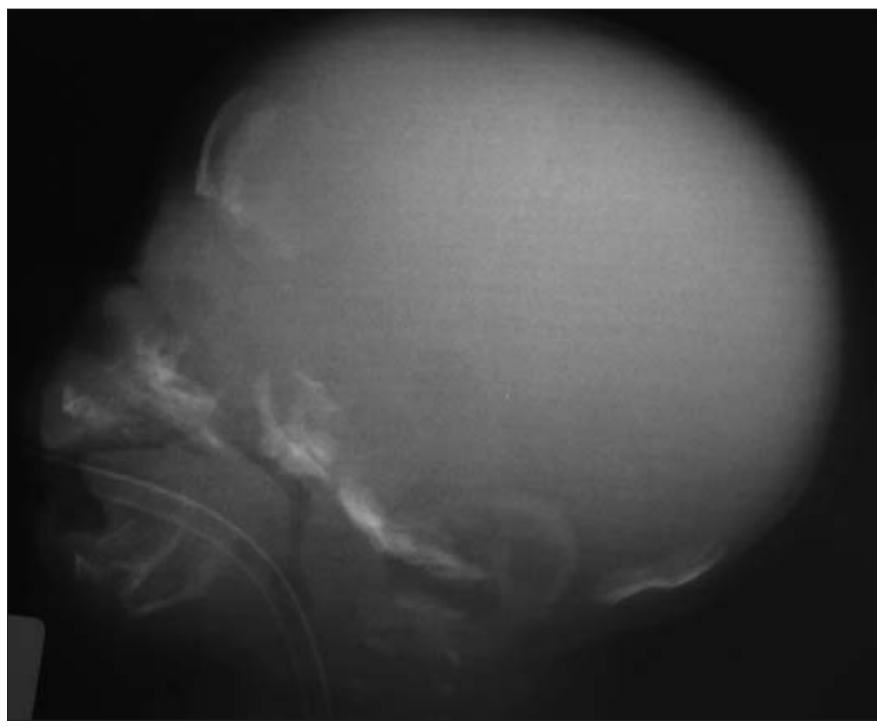

Resim 2. Hastanın kafatasında sadece alt kesimde mineralizasyon dikkati çekiyordu tibiya proksimali femurun distal ucundan daha uzak pozisyonda yer alıp, kısa ve kavislenme göstermekteydi. Her iki tibiyanın proksimalinden itibaren gamzelenme izlenmekteydi (Resim 1).

Radyografide kafa kemiklerinde belirgin mineralizasyon eksikliği ile birlikte sadece frontal, oksipital ve bazal kemikleri izlenmekte olup kafatasının diğer kemikleri görülmemekteydi (Resim 2). Tüm vücut grafisinde klavikulalar ile birlikte ilk iki-üç kosta zorlukla seçilmekteydi. Akciğer parenkim dokusu gelişmemiş ve havalanması yetersiz görünmekteydi. Spinal vertebra cisimleri ince ve belirsiz izlenmekteydi. Humerus, ulna, radiyus, femur ve tibiya kemikleri zayıf mineralize olup, güve yeniği görünümü vermekteydi. Her iki kalça ve tibiya kemikleri çok hipoplazik görünümdeydi (Resim 3).

Laboratuvar değerlendirmesinde serum alkalen fosfatazı (ALP) sirasıyla 3 ve 5 IU/L (normal: 185-350), kalsiyum (Ca) 12 ve $13,3 \mathrm{mg} / \mathrm{dL}$, fosfor $(\mathrm{P}) 6,75$ ve $4,2 \mathrm{mg} / \mathrm{dL}$ olarak ölçüldü. Ekokardiyografisinde duktus açıklığı ve foramen ovale açıklığı dışında önemli kardiyak anomali tespit edilmedi. Karın ve kraniyal ultrasonografileri normal olarak değerlendirildi. Kromozom analizini de içeren diğer laboratuvar bulguları normaldi.

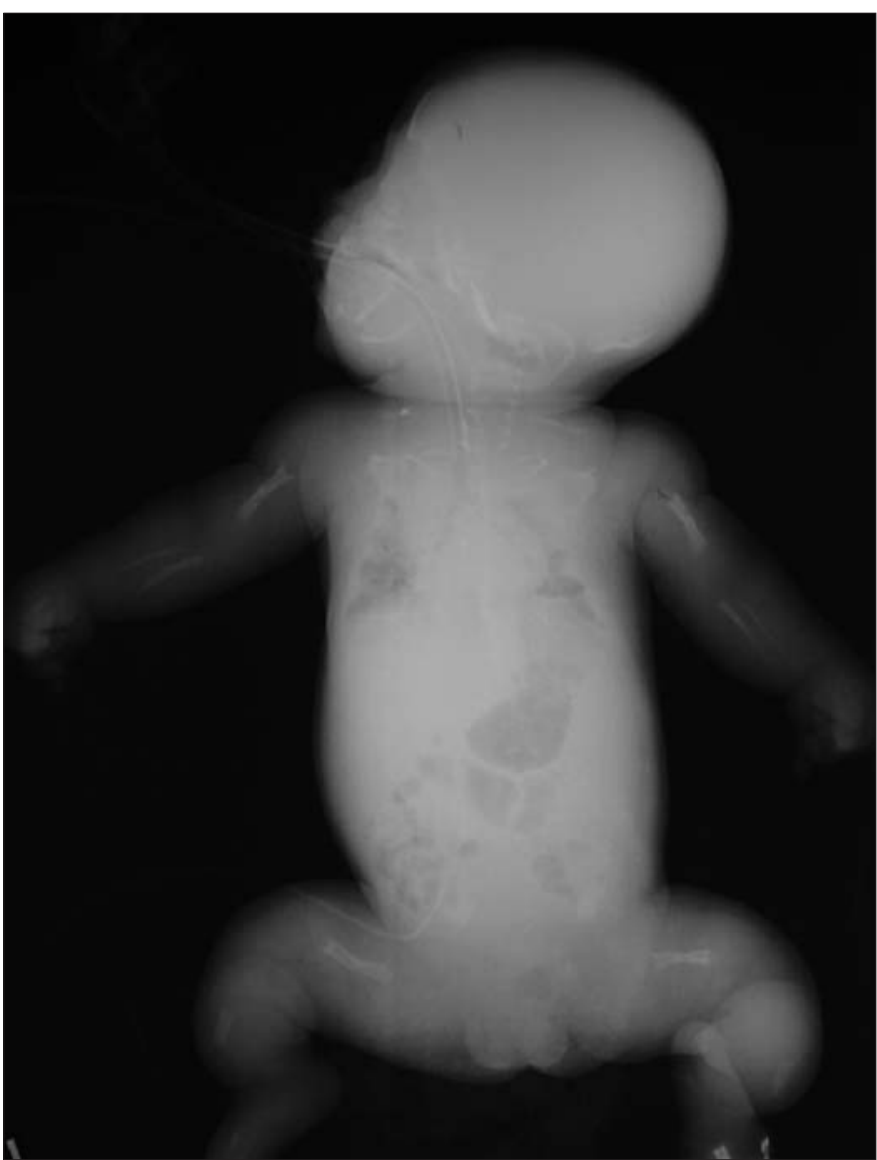

Resim 3. Hastanın tüm vücut grafisinde kemik mineralizasyonu ancak düşük radyasyon dozunda çekim yapıldığında gözlenebiliyordu 
Hasta fizik muayene bulguları, iskelet grafisi ve serum $\mathrm{Ca}, \mathrm{P}, \mathrm{ALP}$ sonuçlarıly birlikte değerlendirildiğinde perinatal letal hipofosfatazya tanısı aldı. Ağır solunum sıkıntısı, interkostal ve subkostal çekilmelerinin olması nedeniyle entübe edilip mekanik ventilatör ile solunum desteği sağlandı. Klinik izleminde küçük ve aşıı esnek göğüs kafesi ve artmış salgıları nedeniyle ekstübasyon gerçekleşmedi ve hasta doğum sonrası 14. günde kaybedildi.

\section{Tartışma}

Perinatal letal tip hipofosfatazya dokuya özgün olmayan ALP enzimini (TNSALP) kodlayan karaciğer/kemik/böbrek alkalen fosfataz gen mutasyonu sonucu gelişir. Enzim dimerik formunda fizyolojik olarak etkin olup, pridoksal fosfat (PP), fosfoetanolamin (PEA) ve inorganik pirofosfatazların (iPP) hücre dışı substratlarını parçalar. Kemik ve diş mineralizasyonu üzerindeki esas etkisi hala açık değildir, ancak IPP'nin (3) ve belki de memelilerdeki kolajen (4) ve Ca bağlama (5) gibi özgül aktivitelerin hidrolizinde görev yapar. Perinatal letal tip hipofosfatazya dokuya özgün olmayan ALP geni 1p36.1 kromozomu üzerinde bulunmaktadır (6). Gen yüksek alel heterojenitesi etkisindedir (7) ve 190'dan fazla farklı mutasyon tanımlanmıştır (8). Mutasyonlardaki bu değişkenlik klinik bulgularda aşırı farklılığa ve heterozigot genotip birleşimlerin çeşitliliğine neden olmaktadır.

Hastalığın şiddeti serum/doku TNSALP aktivitesinin eksikliğinin şiddetiyle orantııdır. Hastalık bizim olguda görüldüğü gibi, doğumda kısa ekstremiteler, yumuşak kafatası, distal ekstremitelerde kavislenme ve belirgin solunum güçlüğü bulguları ile kendini gösterir. Total serum ALP düzeyi belirgin olarak düşüktür. Hastalık ne kadar ciddi ise serum ALP düzeyi o kadar düșüktür (9). Hipofosfatazyanın bu ölümcül formu ile doğan bebekler, genellikle ilk hafta içerisinde azalmış göğüs kafesi hacmi ve hipoplastik akciğerlere bağlı solunum yetersizliğinden kaybedilirler. Bizim olgumuzda en yüksek ALP düzeyi $5 \mathrm{IU} / \mathrm{L}$ idi ve olgu gerek radyolojik gerekse klinik olarak oldukça ağır bir seyir izledi ve doğum sonrası 14 . gününde kaybedildi.

Klinik ve radyolojik bulgularla birlikte düşük serum ALP düzeyleri tanıyı doğrular. Artmış PEA düzeyleri hipofosfatazya tanısını destekler ancak tanı koydurucu değildir (2). Çünkü bazı metabolik hastalarda da yüksek olabileceği gibi, bazı hipofosfatazyalı hastalarda PEA salınımı normal olabilir.

Otozomal çekinik geçişi olan bu hastalıkta anne ve baba zorunlu taşıyıcı olduklarından sonraki gebeliklerde tekrarlama riski \%25'dir. Bu yüzden böyle olgularda DNA analizi mutlaka yapılarak, tanı kesinleştirilir ve aileye genetik danışma desteği sağlanarak sonraki gebeliklerde doğum öncesi tanı ile hastalık önceden tanınabilir. DNA analizi ile ciddi perinatal hipofosfatazyalı hastaların yaklaşık \%95'inde mutasyon saptanır $(2,10)$. Böyle olgularda hasta ölmeden önce DNA analizi için kanı ayrılıp saklanmalı ve olanak olduğunda çalıștırılmalıdır. Hastanın kan örneği moleküler genetik laboratuvarında saklanmış, ancak mutasyon analizinin yurt dıșında yapılması, aileye ekonomik yük getirmesi ve teknik nedenlerden dolayı DNA analizi yapılamamıştır.

Perinatal letal hipofosfatazya tanısının doğum öncesi ultrasonografi ile konulması güçtür çünkü bu tablo osteogenezis imperfekta tip 2 ve akandrogenez/hipokondrogenez gibi diğer iskelet displazileri ile karışabilmektedir (11). Witters ve ark.'ları (12) doğum öncesinde değerlendirdikleri letal hipofosfatazya olgularını da içeren 38 iskelet displazili serilerinde ultrasonografi ile ancak 25 olgunun doğru tanı alabildiğini bildirmişlerdir. Sinico ve ark.'ları (13) üç boyutlu ultrasonografi kullanılması ile 18. gebelik haftasından itibaren letal hipofosfatazya bulgularının daha kolay ve doğru olarak saptanabileceğini göstermişlerdir.

Eksik enzimin yerine konulması gelecekteki bir tedavi yöntemi gibi görünmekteyse de, henüz herhangi bir tedavisi olmayan perinatal letal tip hastalığın doğum öncesi tanısı bu nedenle önemlidir. Doğum öncesi tanı fetal ultrasonografide polihidramniyos ve fetal kemiklerin yetersiz mineralizasyonu, amniyotik sıvı, amniyotik veya koryonik hücre kültürü ALP aktivite ölçümü ile de konulabilir $(2,14)$. Ancak bu olgumuzda görüldüğü gibi doğum öncesi izlemin olmaması nedeniyle tanısı gözden kaçan ölümcül bir hastalıkla doğan yenidoğan ile karşılaşmaktayız. Bu olgu doğum öncesi izlemin önemini göstermekte ve ilk olgu olması nedeniyle bundan sonraki gebeliklerde perinatal letal hipofosfatazya tanısı açısından tam bir değerlendirmeyi zorunlu kılmaktadır.

\section{Kaynaklar}

1. Rathbun JC. Hypophosphatasia: a new developmental anomaly. Am J Dis Child 1948; 75: 822-31.

2. Mornet E. Hypophosphatasia. Orphanet J Rare Dis 2007; 2: 40.

3. Hessle L, Johnson KA, Anderson HC, et al. Tissue-nonspecific alkaline phosphatase and plasma cell membrane glycoprotein1 are central antagonistic regulators of bone mineralization. Proc Natl Acad Sci USA 2002; 99: 9445-9.

4. Hoylaerts MF, Millan JL. Site-directed mutagenesis and epitopemapped monoclonal antibodies define a catalytically important conformational difference between human placental and germ cell alkaline phosphatase. Eur J Biochem 1991; 202: 605-16.

5. Mornet E, Stura E, Lia-Baldini AS, Stigbrand T, Menez A, Le $\mathrm{Du} \mathrm{MH}$. Structural evidence for a functional role of human tissue nonspecific alkaline phosphatase in bone mineralization. J Biol Chem 2001; 276: 3171-8. 
6. Greenberg CR, Evans JA, McKendry-Smith S, et al. Infantile hypophosphatasia: localization within chromosome region 1p36.1-34 and prenatal diagnosis using linked DNA markers. Am J Hum Genet 1990; 46: 286-92.

7. Mornet E. Hypophosphatasia: the mutations in the tissue-nonspecific alkaline phosphatase gene. Hum Mutat 2000; 15: 309-15.

8. Simon-Bouy B, Taillandier A, Fauvert D, et al. Hypophosphatasia: molecular testing of 19 prenatal cases and discussion about genetic counseling. Prenat Diagn 2008; 28: 993-8.

9. Whyte MP. Hypophosphatasia and the role of alkaline phosphatase in skeletal mineralization. Endocr Rev 1994; 15: 439-61.

10. Watanabe A, Yamamasu S, Shinagawa T, et al. Prenatal genetic diagnosis of severe perinatal (lethal) hypophosphatasia. J Nippon Med Sch 2007; 74: 65-9.
11. Zankl A, Mornet E, Wong S. Specific ultrasonographic features of perinatal lethal hypophosphatasia. Am J Med Genet A 2008; 146: 1200-4.

12. Witters I, Moerman P, Fryns JP. Skeletal dysplasias: 38 prenatal cases. Genet Couns 2008; 19: 267-75.

13. Sinico M, Levaillant JM, Vergnaud A, et al. Specific osseous spurs in a lethal form of hypophosphatasia correlated with 3D prenatal ultrasonographic images. Prenat Diagn 2007; 27: 222-7.

14. Warren RC, Rodeck CH, Brock DJH, McKenzie CF, Moscoso $\mathrm{G}$, Barron L. First trimester diagnosis of hypophosphatasia with a monoclonal antibody to liver/bone/kidney isoenzyme of alkaline phosphatase. Lancet 1985; 19: 856-8. 